\title{
Human Resource Development Program in Strengthening Lecturer Competence in Indonesia
}

\author{
Ali Rohmad \\ Institut Agama Islam Negeri Tulungagung, Indonesia \\ \{alirohmad@iain-tulungagung.ac.id\}
}

\begin{abstract}
This research refers to the vocational self-concept theory, applying a fundamental paradigm (naturalistic paradigm) that relies on the views of phenomenology, qualitative approaches and with multisite research designs. The human resources development program in strengthening lecturer competencies is an annual work plan which includes: lecturer development plans, lecturer selection, and evaluation processes, the process of awarding employee benefits and opportunities for professional development and lecturers' careers.
\end{abstract}

Keywords: Competencies of Lecturers, Human Resources and Islamic Universities.

\section{Introduction}

In Islam as the revelation of Allah SWT as contained in the Holy Qur'an and the books of the Prophet Muhammad SAW some teachings regulate the relationship between humans and their livelihoods [what is meant by sustenance is the maintenance of life, subsistence] [1]. For example, in the holy book al-Qur'ān the ninth letter of al-Taubat verse 105, Allah SWT said:

"And say: Work on you, then Allah and His Messenger and the believers will see that work, and you will be returned to (Allah) the Knower of the unseen and the real, then He will tell you what you have to do it." [2].

In the text of the revelation it contains the teachings that humans pursue a field of work as guidance to get success; both in the internal sense that is for individuals who seek employment, as well as in an external mind, namely for organizations that are trying to form a path to developing work that is worthy of being followed throughout work life [3].

Lecturer coaching is an effort to maintain / empowerment of "lecturer competencies" through some activities so that the concerned will survive better in his profession through the ability to provide excellent service as the carrying out of academic tasks reflecting the primary duties and functions as contained in the tri dharma of higher education [4].

Lecturers are the primary role holders of the realization of the tertiary tri dharma (UndangUndang Republik Indonesia No. 20 Th. 2003 Pasal 20 Ayat 2). The seriousness of the lecturer in actualizing the tri dharma of higher education is a determinant for the formation of image quality of graduates and the quality of institutions in general.

Human resources include two components of personnel capability and personal commitment. It is right when the creation of human resource management has always been a problem for the survival of every organization. Thus, human resource management must get seriously planned administration again and again, including professional development and lecturer careers, in line with the dynamics of changing times which are currently entering the 
era of globalization which is increasingly loaded with competition in all aspects of life. Each Lecturer must master four types of lecturer competencies: pedagogic competence, professional competence, social competence, personality competence [5].

\section{Literature review}

\subsection{Characteristics of State Islamic Religious Colleges}

Islamic Higher Education (PTI) is a high-level educational and teaching institution in the formal education pathway whose commitment to the Qur'an and al-Sunnah of the Prophet SAW is a manhaj in the development of scientific culture for the academic community to graduate scholars who have Islamic intellectual property for dynamics Islamic civilization.

At present, the designation of the State Islamic College (PTIN) has been renewed to become the State Islamic Religious College (PTKIN). In Indonesia, there are three types of PTKIN: UIN, IAIN, and STAIN. The management of these three types of PTKIN is structurally and functionally under the auspices of the Ministry of Religion of the Republic of Indonesia, while technically academic is managed by the Ministry of Research, Technology and Higher Education (Kemenristekdikti). Besides that, there are also institutions and high schools as Private Islamic Religious Colleges (PTKIS) which are managed by the private sector [6].

\subsection{The human resource development program}

Every organization, both business organizations, and non-business organizations, wants the human resources they have to contribute as much as possible to the achievement of organizational goals. Humans are labor in the organization. Only humans always play an active and dominant role in every activity of the organization; humans become planners, actors, and determinants of achieving organizational goals [7].

The human resource development program must be directed at expanding the horizons and individual capabilities [8] lecturers to be more creative and innovative in realizing the tri dharma of higher education; so that there is an increase in the quality of the position of a stakeholder's position or work on his profession including the degree of knowledge and expertise he has in carrying out professional duties, and then there is an increase in career effectiveness with four characteristics: career performance as an indication height of individual performance level, career attitude as an indication of a positive attitude in how individuals perceive and evaluate their careers, career adaptability as an indication of the application of knowledge and expertise and technology by individuals in their jobs, career identity as an indication of the level of individual awareness regarding interests, values, future expectations as well as the level of consistency of the individual's life [9].

\subsection{Vocational Self-Concept Theory}

The basic concept of several theories that are expected by the author, one of which can be used as a reference in this study. Some of the arguments contained in the three books are Trait-and-Factor Theory by Frank Parsons, Theory of Occupational Choice by Ginzberg, Vocational Self-Concept Theory by Donald E. Super, Self-Development Theory by David Tiedeman, a Need-Theory Approach to Career Choice by Ann Roe, Holland's Theory by John Holland [10]-[12]. 
The multidisciplinary approach to career development used by Donald E. Super [13] is reflected in his interest in differential psychology or trait-and-factor theory as a medium for developing instrument testing and accompanying assessment norms. He argues that differential psychology is critical to enriching data about functional differences related to personality, aptitude, and interest.

The self-concept theory is an essential part of Donald E. Super's approach to vocational behavior. The results of the study [14]-[18] show that vocational self-concepts develop through physical and mental growth, observation of working life, identifying adults who work, general environment, and experience in general. In the end, differences and similarities between yourself and others will be assimilated. If the knowledge related to the world of work has become broader, better vocational self-concepts will also be formed. Although professional self-concept is only part of the overall concept of self, the idea is the driving force that creates the pattern of work that will be followed by individuals throughout their lives. The individual implements his concept of self into a profession that will be the most efficient means of expressing himself.

\section{Result and discussion}

The human resource development program in strengthening the competence of lecturers obtained several equations as cross-site research findings regarding human resource development programs in increasing lecturer competence conducted by STAIN Kediri and Ponorogo IAIN as indicated by the tendency: Development of higher education institutions became an active organization; Making skilled lecturers, experts and professionals; Planning based on internal-external demands; The better management system (recruitment, placement, reward, coaching); Lecturers are facilitated to participate in training, seminars, research, lecturer associations, collaboration; Lecturers are aided further study to Ph.D. program; Candidate recruitment system for Civil Servants (CPNS) through the ministry of religionMinistry of Administrative Reform and Bureaucratic Reform; CPNS selection lecturers utilize Computerized Assistence Technique (CAT) to test Basic Competency Selection and Field Competency Selection; Objective, transparent principle in the selection of lecturer CPNS; Qualifications of a minimum S2 linear diploma in the range of lecturer CPNS; Implement the Standard Operating Procedure (SOP) in the process of placement, retention, dismissal; Monitoring lecturer performance through syllabus, attendance, lecture module; Lecture facilities based on Information and communications technology (ICT); and track record of academic academic achievement through reports on Lecturer Workload and Employee Performance Objectives.

\section{Conclusion}

The HR development program in strengthening lecturer competencies is an annual work plan which includes: a. Strategies for developing lecturer human resources, b. Policies and procedures in the process of selecting and evaluating lecturers, c. Programs and procedures in the process of awarding employee benefits, $d$. Plans to provide professional development opportunities and lecturer careers.

Universities that want to survive and succeed must always pay attention to the development of human resources such as educators or lecturers, among others by fulfilling the right to get professional and career coaching. This kind of attention to the development of 
human resources (HR) will encourage lecturers to explore potential abilities. This is realized because HR development is one of the needs of lecturers to be able to actualize themselves towards work.

\section{References}

[1] Tim Penyusun, Kamus Besar Bahasa Indonesia. Jakarta: Balai Pustaka, 1995.

[2] F. ibn “Abd al-"Azīz Al-Sa'ūd, Al-Qur'an dan Terjemahnya. Madînah alMunawwarah: Mujamma' al-Mālik Fahd li Thibā'ah al-Mushhaf al-Syarîf, 1418.

[3] A. Ikhwan, "Sistem Kepemimpinan Islami: Instrumen Inti Pengambil Keputusan pada Lembaga Pendidikan Islam," Istawa J. Pendidik. Islam, vol. 3, no. 2, p. 111, Jan. 2018

[4] A. Ikhwan and D. I. Jaelani, "Introduction to the Islamic Education Concepts (an Integral Paradigm Building Efforts)," in Proceedings International Seminar on Islamic Law, Economic, Education, and Science, 2014, pp. 136-147.

[5] Kementerian Pendidikan dan Kebudayaan, Buku Pedoman Sertifikasi Pendidik untuk Dosen (SERDOS) Terintegrasi, Buku 1 Naskah Akademik. Jakarta: Direktorat Jenderal Pendidikan Tinggi Kementerian Pendidikan dan Kebudayaan, 2015.

[6] A. Rohmad, "Pembinaan Sumber Daya Manusia dalam Penguatan Kompetensi Dosen Perguruan Tinggi Keagamaan Islam Negeri (Studi Multisitus di STAIN Kediri dan IAIN Ponorogo)," Universitas Islam Negeri Maulana Malik Ibrahim Malang, 2018.

[7] A. Ikhwan, "Sistem Kepemimpinan Islami: Instrumen Inti Pengambil Keputusan pada Lembaga Pendidikan Islam," Istawa J. Pendidik. Islam, vol. 3, no. 2, pp. 111-154, 2018.

[8] M. A. Ma'arif, "Analisis Konsep Kompetensi Kepribadian Guru PAI menurut AzZarnuji,” Istawa J. Pendidik. Islam, vol. 2, no. 2, p. 35, Sep. 2017.

[9] H. Simamora, Manajemen sumber daya manusia. Jakarta: STIE YKPN, 2004.

[10] V. G. Zunker, Career Counseling Applied Concepts of Life Planning. Pacific Grove, California: Brooks/Cole Publishing Company, 1990.

[11] D. Brown and L. Brooks, Career Choice, and Development. London: Jossey-Bass Publisher, 1987.

[12] H. J. Peters and J. C. Hansen, Vocational Guidance and Career Development. New York: The Macmillan Company, 1971.

[13] D. E. Super and D. J. Forrest, Career Development Inventory, Form I: Preliminary manual. New York: Teachers College, Columbia University, 1972.

[14] G. Norrell and H. Grater, "Interest awareness as an aspect of self-awareness," $J$. Couns. Psychol., vol. 7, no. 4, p. 289, 1960.

[15] M. E. Englander, "A psychological analysis of vocational choice: Teaching," J. Couns. Psychol., vol. 7, no. 4, pp. 257-264, 1960.

[16] A. K. Kibrick and D. V. Tiedeman, "Conception of self and perception of role in schools of nursing.," J. Couns. Psychol., vol. 8, no. 1, pp. 62-69, 1961.

[17] D. H. Blocher and R. A. Schutz, "Relationships among self-descriptions, occupational stereotypes, and vocational preferences.," J. Couns. Psychol., vol. 8, no. 4, pp. 314 317, 1961.

[18] T. B. Anderson and L. C. Olsen, "Congruence of Self And I deal-Self And Occupational Choices," Pers. Guid. J., vol. 44, no. 2, pp. 171-176, Oct. 1965. 